\title{
Relationship Between Technology and Social Development: a Worldwide Assessment with Conclusions for Eastern Europe
}

\author{
László A. Poók and Norman Pence \\ Metropolitan State College of Denver, USA
}

pookt@wortdnet.att.net and pencen@mscd.edu

\begin{abstract}
Internet penetration into economies around the world has been shown to be spotty at best. Yet, electronic commerce has been identified as the engine behind the growth of wealth and social development. It is forecasted to remain a driving force behind economic growth in the foreseeable future. National leaders of the Big 8 conference in Okinawa, Japan in June 2000 were vowing to eliminate, or at least reduce the "digital divide" plaguing some nations limiting their economic development. This paper examines the effects of high technology on economic activity in nations around the world. It examines commonalities among nations, which remain economically and technologically backward and attempts to highlight the prerequisites to reaping the benefits of technology, specifically of information technology and electronic commerce. The authors discuss whether technologically backward regions should investment in high technology to leapfrog into the future and to sudden wealth.
\end{abstract}

Keywords: Information infrastructure, technology, social development, Eastern Europe.

\section{Background}

Electronic commerce has been identified as the engine behind the growth of wealth and social development in the US in more recent times. It is forecasted to remain a driving force behind economic growth in the foreseeable future. National leaders of the Big 8 conference in Okinawa, Japan in June 2000 were vowing to eliminate, or at least reduce the "digital divide" plaguing some nations limiting their economic development. What effects of high technology can be observed in other nations? What are some of the commonalities among those nations, which remain economically and technologically backward? What are the prerequisites to reaping the benefits of technology, specifically of information technology and electronic commerce? Can the benefits of high technology be expected to trickle to less fortunate nations? Should technologically backward regions use investments in high technology to leapfrog into the future and to sudden wealth?

Material published as part of this proceedings, either on-line or in print, is copyrighted by the author with permission granted to the publisher of Informing Science for this printing. Permission to make digital or paper copy of part or all of these works for personal or classroom use is granted without fee provided that the copies are not made or distributed for profit or commercial advantage AND that copies 1) bear this notice in full and 2) give the full citation on the first page. It is permissible to abstract these works so long as credit is given. To copy in all other cases or to republish or to post on a server or to redistribute to lists requires specific permission from the author.
In a speech to the European American Business Council, Assistant Secretary of NTIA Gregory L. Rhode stated that,

"Statistics show that Internet penetration is happening unevenly around the world, unevenly even throughout Europe. According to statistics from May, there are about 108 million Internet users in Europe, for a penetration rate of $34 \%$. That figure varies from $65.2 \%$ in Sweden to $45.6 \%$ in the U.K., $31.6 \%$ in France and $11.4 \%$ in Portugal. Worldwide, we see even greater disparities. According to the Computer Industry Almanac report from last November, there were 57.5 Internet users per 1,000 people on a worldwide average. That ranged from a high of 492 Internet users per 1,000 people in North America, to 7.88 users per 1,000 people in the Middle East and Africa." (Rhode, 2000)

UNESCO (United Nations Education Science and Cultural Organization) was founded on the basic premise that information is not only a necessity to all human beings but a human right. Furthermore, the ITU (International Telecommunication Union) stresses that communication and communication infrastructures are preconditions for economic and social development (Ferguson, 2000). In other 


\section{Technology and Social Development}

words UNESCO implies and the ITU states direct causality between economic and social development and information infrastructures, and by implication, technology as well.

Peter Meso (1999) examined the relationship between social development and geographic region as well as the importance of components of the NII (National Information Infrastructure) and social development among LDC's (Least Developed Countries) and found that geographic region is not a significant indicator of social development and only telephone density is a significant predictor of social development among NII components. However, he did find that NII variables explain only about $50 \%$ of LDC social development.

Internet related activities including education, commerce, and news dissemination are intimately dependent on communications technology, which in turn is the merging of telecommunication, mass media, and information technology (Ferguson, 2000). Do nations of the world possess at least roughly similar levels of these technologies to take advantage of the Internet? If not, then why not? Are the reasons economic, cultural, political, or other? Since some nations are much poorer than others, it is reasonable to argue that foreign developers are wont to invest in unprofitable regions and the indigenous populations cannot finance the high cost of technology development from their own budgets giving priority to other, more pressing needs. In fact the World Bank is supporting a pipeline development, a low-tech project, between Chad and Cameroon rather than Internet development, and is working to combat poverty rather than finance high technology projects in LDC's (The Wall Street Journal Europe, 2000).

\section{Data used}

To assess the level of technology in countries the following published data were used: Numbers of personal computers, High-technology exports, High technology investment, Internet hosts per million population, Number of users of Internet per million population, Low technology investment $\%$, Medium technology investment $\%$, Primary education participation rate, GDP per capita, (Purchasing Power Parity (PPP) in constant 1987 international dollars), Literacy rate, adult total, Newspapers per 1000 population, Radios per 1,000 population, Television sets per 1,000 population, Telephone mainlines per 1,000 population, Infant mortality rate, Health care $\%$ of population with access, Safe water $\%$ of population with access, and Life expectancy at birth. Not all data are available and conclusions drawn must take into account consequent inaccuracies.

Data items in the above set are measured on different scales. To avoid erroneous results all variables were stan- dardized into z-scores, using their means and standard deviations resulting in essentially the same distributions without certain variables overpowering others.

Data sources were the World Bank, World Development Indicators 2000, UNESCO 1999, United Nations, Women's Indicators and Statistics Database 1999, The International Telecommunications Union (ITU) 1996/97, Telcordia Technologies Website 2000, Industrial Development: Global Report (UNIDO) 1997, CIA World Factbook 1999, and the International Labor Organization databases 1999.

\section{Hypotheses and Methodology}

It is argued that countries in similar circumstances display similar social, economic, and technical characteristics. Where these characteristics are numerically measurable, they can be used to identify and group countries which have similar development histories and predict from their collective situations their short-term economic development and technological futures.

The statistical methodology used was cluster analysis by SPSS (Statistical Package for the Social Sciences). Cluster analysis identifies relatively homogeneous groups of countries based on the selected variables. Using F statistics the procedure finds groups, which are indeed different. In order to match the World Bank's grouping of countries by income classes, four clusters were defined. Three analyses were performed.

$\mathrm{H} 1$ : in an attempt to examine if social indicators as defined by the World Bank do indeed cluster countries into similar groups on social measures the first cluster used literacy, primary education, infant survival, access to health care and safe water, life expectancy, and per capita GDP. To test if our four socio-economic clusters differ from the World Bank model, income classes were further subdivided into the four resulting clusters.

H2: to test Peter Meso's (1999) theory that poor countries are located mostly in Africa, the clusters were further subdivided by continent.

H3: if Internet technologies are dependent on more basic communication technologies, such as telecommunication, mass media, and information technology as stated by Ferguson, (2000) then it must also be true that nations without adequate base technologies are less likely to develop hightechnology Internet based economies. Communications technologies should also help cluster these countries into the familiar four groups achieved above. To examine this hypothesis the second cluster was for information infra- 
structure measured by telephone mainlines, television sets, radios, and newspapers.

H4: after a country establishes a basic communications industry, it then has the base on which to build an Internet and e-commerce economy. Because the industrial application of technology is considered to be an important ingredient in raising productivity, it is expected that per capita GDP also plays an important role in determining cluster membership. The third cluster was for available technology measures such as high-technology exports, high-

technology investments, low technology investments, medium technology investments, personal computers, Internet users, Internet hosts, and GDP per capita. It is expected that the resulting clusters will again display similar continent and income class memberships as for the previous clusters and further highlight the need for the presence of low and medium technology industries before high technology can take root.

\section{Results}

Clusters of the social indicator variables described above resulted in variable descriptors for the undeveloped nations (Table 1, Cluster 1) as follows. Some countries located in cluster 1, Under Developed Nations, are Afghanistan, Chad, Ethiopia, Sudan, etc.

Nations located in the group labeled Developing Nations (Cluster 2) display descriptive characteristics as in Table 2. Some of the countries located among cluster 2 nations are Bangladesh, Gabon, Malawi, Nepal, Swaziland, Zimbabwe, etc.

Nations located in the group labeled Rapidly Developing Nations (Cluster 3) display the following descriptive characteristics in Table 3. Among these nations are the exSoviet nations and newly independent republics of the USSR. These are Armenia, Azerbaijan, Belarus, Bosnia and Herzegovina, Bulgaria, Croatia, Czech Republic, Estonia, Georgia, Hungary, Kazakhstan, Kyrgyz Republic, Latvia, Lithuania, Macedonia FYR, Moldova, Poland, Romania, Russian Federation, Slovak Republic, Slovenia, Tajikistan, Turkmenistan, Ukraine, Uzbekistan, and Yugoslavian FR, as well as Ecuador, Jamaica, Jordan, Mexico, Portugal, Venezuela, etc.

Developed Nations clustered into group 4. Their descriptive statistics can be found in Table 4. Nations clustering into this group include most western and northern European nations, USA, Singapore, Australia, Bahrain, Brunei, etc.
In order to examine if our clustering is different from the World Bank (WB) income groups our clusters were plotted against the four income classifications of the WB in Figure 1. Figure 1 indicates that there is a strong correspondence between the World Bank income categorization and the clustering here on social development. The low-income category by the World Bank consists of about equal numbers of under developed and developing nations clusters from the clustering achieved here. We can be confident that our clustering effort achieves reliable consistency.

On this basis $85.3 \%$ of low income countries are underdeveloped and developing according to our social development index; $94 \%$ of lower middle-income countries are developing or rapidly developing countries; $75 \%$ of upper middle-income countries are rapidly developing; and $94.9 \%$ of high-income nations are developed.

Figure 2 indicates that while Asian nations are represented at all levels of development, African nations are heavily weighted toward under developed and developing countries. Of the Underdeveloped Nations $10 \%$ of them are located in Asia and the remaining 90\% are in Africa. None of the Developing Nations are in Europe or North America. Of the Rapidly Developing nations $23.3 \%$ are in Europe; an overwhelming majority of them are ex-USSR states or recently liberated satellite states. The rest of Europe belongs to the group of developed nations, South America is primarily rapidly developing, and North America consists of developed nations only. Level of social development then appears to be linked to continent

Clusters of the information infrastructure (II) variables resulted in variable descriptors for the Poor Information Infrastructure Nations (cluster 1) as shown in Table 5. Some countries located in cluster 1 are Afghanistan, Chad, Ethiopia, Sudan, Zimbabwe, etc. as before. In addition many of the ex-USSR states such as Azerbaijan, Armenia, Tajikistan, Turkmenistan, Uzbekistan, can be found here as well as Bosnia and Herzegovina, Macedonia FYR, and Yugoslavia FR.

Cluster 4, Developing Information Infrastructure Nations, can be described by the statistics in Table 6 . The remainder of the ex-USSR states are located in this group as well e.g. Belarus, Bulgaria, Czech Republic, Georgia, Hungary, Kazakhstan, Latvia, Lithuania, Moldova, Poland, Romania, Russian Federation, Slovak Republic, Slovenia, and Ukraine. Some of the other countries here are Argentina, Belize, Italy, Malawi, Qatar, etc.

Cluster 3, Rapidly Developing Information Infrastructure Nations descriptive characteristics can be found in the Ta- 


\section{Technology and Social Development}

ble 7. Among the third cluster group are some European nations e.g. Austria, Belgium, Germany, Liechtenstein, Netherlands, Norway, Switzerland, and Sweden. Also, Singapore and the single ex-communist state of Croatia are located among the Rapidly developing Information Infrastructure Nations.

Among the Well Developed Information Infrastructure Nations represented by Cluster 2, in Table 8 , we find Australia, Canada, Finland, France, Spain, UK, USA, etc.

Clustering within the Social Development Indicators and the Information Infrastructure variables appear to be parallel: underdeveloped nations will display poor information infrastructures while developed nations enjoy welldeveloped information infrastructures. Similarly, developing and rapidly developing countries cluster into developing and rapidly developing information infrastructure nations.

Graphical review of the data reveals that low to lower middle income countries have poor information infrastructures while upper middle to high income countries enjoy rapidly developing to well developed information infrastructures (see Figure 3).

Furthermore, most of the African and Asian continents suffer with poor information infrastructures while the bestdeveloped information infrastructures are found in Europe and North America (see Figure 4). It should be noted that $48.8 \%$ of Developing II nations and $9.8 \%$ of Poor II nations in Europe are made up of the ex-USSR and her satellite states.

Clusters of technology variables resulted in variable descriptors for the technology poor nations (cluster 2) as shown in Table 9. Some countries located in cluster 1 are Afghanistan, Argentina, Chad, Ethiopia, Sudan, Swaziland, Zimbabwe, etc. as before. In addition many of the exUSSR states of Azerbaijan, Armenia, Georgia, Kazakhstan, Kyrgyz Republic, Tajikistan, Turkmenistan, Ukraine, Uzbekistan, can be found here as well as many of the exSoviet sphere states of Bosnia and Herzegovina, Hungary, Latvia, Lithuania, Macedonia FYR, Moldova, Poland, Romania, Russian Federation, and Yugoslavia FR.

Technology variable descriptors for nations with beginning technology development are displayed in Table 10. Some representative nations from this group are Bhutan, Gabon, Mexico, Qatar, Saudi Arabia, Singapore, and South Africa, as well as the ex-Soviet sphere country of Bulgaria, and the west European country of Ireland.
Variable descriptors for rapidly evolving technology nations are displayed in Table 11. Among these nations are clustered the European nations of Austria, Belgium, France, Germany, Italy, Liechtenstein, Luxembourg, Spain, and the UK, as well as the ex-Soviet sphere states of the Czech and Slovak Republics, and Slovenia.

Descriptor variables for the technology leader countries are in Table 12. Among these are Australia, Canada, Iceland, the Netherlands, New Zealand, the Nordic nations, Switzerland, and the USA.

From Figures 5 and 6 it should be clear from earlier analysis, that technology poor nations are those classified as low income and lower middle income. They are concentrated in Asia and Africa. In fact $61.3 \%$ of technology poor nations are on those continents as are $50.3 \%$ of beginning technology nations. Put in another way $45 \%$ of technologically deprived nations are on the Asian and African continents. In contrast, $47.6 \%$ of European nations are also technologically deprived and most of these are ex-Soviet sphere nations. This illustrates the lack of available technology infrastructure maintained by Soviet policy makers, which is now making its impact felt on those nations.

In order to test similarity of cluster membership using clusters of social indicators, information infrastructure, and technology a non-parametric test was performed. Using Kendall's W test for measure of agreement yielded a value of 0.605 for overall agreement, which is an acceptable value indicating similarity of membership among the three clusters. That is, largely the same countries belong to the group classified as underdeveloped social indicators, with poor information infrastructure, and technologically poor; and similarly, largely the same countries belong to the group classified as well developed social indicators, with well developed information infrastructure, and technology leader, etc.

\section{Interpretation}

Figure 2 depicts the relationship between social development and continent. It should be clear that underdevelopment is primarily limited to Asia and Africa whereas advanced social development is found primarily in Europe and North America. These observations support Peter Meso's (1999) conclusions regarding poverty, information infrastructures, and continents and our Hypothesis 1 and 2 (H1 and $\mathrm{H} 2$ ).

Communist governments left their peoples with dismal communications infrastructures as this was demonstrated in Figures 3 and 4 above. This stands to reason since commu- 
nication within and outside these countries was not to the regime's benefit. Equally alarming is the fact that $17.5 \%$ of the nations in this study with their well developed to rapidly developing information infrastructures are leaving the remainder of the world behind on their way to harnessing productivity and income gains to benefit their societies. The rest are busy developing basic industries such as communications technologies to base high technology industries on in the future. Countries without the necessary information infrastructures are likely those with few social amenities as well who need to develop basic necessities first. Kendall's W test further confirms this observation. This conclusion supports hypothesis three (H3).

Comparing the list of countries classified among underdeveloped and developing nations on social development to those classified as technologically poor and beginning technology nations it becomes apparent that these are mostly the same countries. Furthermore countries with poor to developing information infrastructures are also the ones who suffer with backward technologies. Hypothesis 4 is further confirmed by Kendall's W test above. Leapfrogging from backwardness to high technology and e-commerce is not likely to occur without first investing in basic human needs, and then in low- and medium- technology sectors. These observations support our fourth hypothesis (H4).

At the conclusion of the eight nation monetary conference in Okinawa, Japan, in July 2000, leaders of those nations vowed to bring the rest of the world up to the level of the technology leaders in order to reap the benefits of hightechnology. That day is long in coming and is not likely to be speeded up without significant aid from advanced and wealthier nations. Investments in high technology projects are expensive and even wasteful without also investing in basic human needs and basic technologies first. When poor nations invest $90 \%$ of their GDP in low- and mediumtechnology projects just to catch up on basic social needs, it is difficult to imagine them spending 20 to $40 \%$ of their GDP on high-technology.

\section{In conclusion}

Does the use of high technology contribute equally to the development of nations? No, it does not. It contributes to the development of only $7.7 \%$ of the countries' economies, and including rapidly developing technology nations, that figure increases to only $22.2 \%$. Low and medium technologies have a perceptibly higher impact on the welfare of under developed nations and their investment patterns bare this out as reported by UNIDO (1997). In comparing data from 1997 to 1994 the UNIDO report sug- gests that most South American, African, and Asian countries are reducing high technology investments and increasing investments in low and medium technologies.

Is communications technology more important in some cases than high technology? Yes, for less than developed nations building basic infrastructures is more important than investing in high technology. This conclusion was reached by many ex-Soviet sphere nations as can be seen in Table 13 (UNIDO, 1997). With the exception of Slovenia they all reduced high technology investments during the period. Slovenia increased investments in medium and high technology because of its dismally low investment rates in the 70's. For developed nations where information infrastructures are in place high technology will remain the driver behind productivity gains for the foreseeable future ("Why the Productivity Revolution will Spread," 2000). Other nations, mostly with outside financial help, will have to play catch-up.

Which components of telecommunications contribute to social development? Though this study does not directly address this question logic suggests that basic information technologies have more of a direct affect on social development than high technology based programs. UNIDO (1997) reports that $80.1 \%$ of East and South-East Asian growth between 1970 and 1995 was generated by the basic industries of agriculture, manufacturing, and services; not by high technology.

What aspect(s) of high technology contribute(s) more to social development? To the extent that high technology requires the development of low- and medium-technologies first traditional industry development is first needed before high technology can make its effects felt. With this relationship in mind, many African nations are inviting basic industry investments now and abandoning the high technology bandwagon ("Investment in Africa: More than Expected," 2000). 
Table 1. Descriptive Statistics for Cluster 1: Underdeveloped Nations

\begin{tabular}{|l|r|r|r|r|r|}
\hline & $\mathrm{N}$ & \multicolumn{1}{|c|}{ Minimum } & \multicolumn{1}{c|}{ Maximum } & \multicolumn{1}{c|}{ Mean } & \multicolumn{1}{c|}{$\begin{array}{c}\text { Std. } \\
\text { Deviation }\end{array}$} \\
\hline $\begin{array}{l}\text { Literacy rate, adult total } \\
\text { (\% of people 15+) }\end{array}$ & 29 & 19.20 & 67.80 & 43.3793 & 12.4220 \\
$\begin{array}{l}\text { Primary education } \\
\text { particip. rate. (\%) }\end{array}$ & 24 & 29.00 & 89.00 & 62.2917 & 14.8309 \\
$\begin{array}{l}\text { Infant survival (\%) } \\
\text { (100-mortality) }\end{array}$ & 30 & 81.71 & 93.67 & 88.8400 & 2.7946 \\
$\begin{array}{l}\text { Health care (\% of } \\
\text { population with access) }\end{array}$ & 26 & 12.50 & 79.33 & 43.0538 & 18.1229 \\
$\begin{array}{l}\text { Safe water (\% of } \\
\text { population with access) } \\
\text { Life expectancy at birth, } \\
\text { total (years) }\end{array}$ & 29 & 13.33 & 95.00 & 39.7293 & 18.1147 \\
$\begin{array}{l}\text { GDP per capita, PPP } \\
\text { (constant 1987 } \\
\text { international \$) } \\
\text { Valid N (listwise) }\end{array}$ & 30 & 35.83 & 54.35 & 48.1339 & 4.5034 \\
\hline
\end{tabular}

Table 2. Descriptive Statistics for Cluster 2: Developing Nations

\begin{tabular}{|l|r|r|r|r|r|}
\hline & $\mathrm{N}$ & Minimum & Maximum & \multicolumn{1}{c|}{ Mean } & \multicolumn{1}{c|}{$\begin{array}{c}\text { Std. } \\
\text { Deviation }\end{array}$} \\
\hline $\begin{array}{l}\text { Literacy rate, adult tota } \\
\text { (\% of people 15+) }\end{array}$ & 40 & 27.50 & 93.70 & 66.9625 & 15.2231 \\
$\begin{array}{l}\text { Primary education } \\
\text { particip. rate. (\%) } \\
\text { Infant survival (\%) }\end{array}$ & 30 & 79.00 & 162.00 & 105.0333 & 18.1383 \\
$\begin{array}{l}\text { (100-mortality) } \\
\text { Health care (\% of } \\
\text { population with access }\end{array}$ & 43 & 86.65 & 97.40 & 93.1938 & 2.4305 \\
$\begin{array}{l}\text { Safe water (\% of } \\
\text { population with access } \\
\text { Life expectancy at birth } \\
\text { total (years) }\end{array}$ & 43 & 12.90 & 77.00 & 49.3027 & 14.7696 \\
$\begin{array}{l}\text { GDP per capita, PPP } \\
\text { (constant 1987 }\end{array}$ & 44 & 478.76 & 5834.77 & 1784.498 & 1201.4067 \\
$\begin{array}{l}\text { international \$) } \\
\text { Valid N (listwise) }\end{array}$ & 23 & & 68.86 & 59.3145 & 5.9477 \\
\hline
\end{tabular}

Table 3. Descriptive Statistics for Cluster 3: Rapidly Developing Nations

\begin{tabular}{|c|c|c|c|c|c|}
\hline & $\mathrm{N}$ & Minimum & Maximum & Mean & $\begin{array}{c}\text { Std. } \\
\text { Deviation }\end{array}$ \\
\hline $\begin{array}{l}\text { Literacy rate, adult total } \\
\text { (\% of people } 15+\text { ) }\end{array}$ & 74 & 61.60 & 99.00 & 90.8554 & 8.9143 \\
\hline $\begin{array}{l}\text { Primary education } \\
\text { particip. rate. (\%) }\end{array}$ & 59 & 69.00 & 133.00 & 102.0847 & 13.6373 \\
\hline $\begin{array}{l}\text { Infant survival (\%) } \\
\text { (100-mortality) }\end{array}$ & 85 & 93.48 & 99.35 & 97.6470 & 1.2643 \\
\hline $\begin{array}{l}\text { Health care (\% of } \\
\text { population with access) }\end{array}$ & 45 & 44.50 & 100.00 & 93.2044 & 10.7186 \\
\hline $\begin{array}{l}\text { Safe water (\% of } \\
\text { population with access) }\end{array}$ & 61 & 35.65 & 100.00 & 82.2839 & 14.0192 \\
\hline $\begin{array}{l}\text { Life expectancy at birth } \\
\text { total (years) }\end{array}$ & 86 & 59.19 & 76.61 & 70.4878 & 3.2318 \\
\hline $\begin{array}{l}\text { GDP per capita, PPP } \\
\text { (constant } 1987 \\
\text { international \$) }\end{array}$ & 85 & 800.00 & 9924.03 & 4257.295 & 2372.7528 \\
\hline Valid N (listwise) & 28 & & & & \\
\hline
\end{tabular}

Table 4. Descriptive Statistics for Cluster 4: Developed Nations

\begin{tabular}{|c|c|c|c|c|c|}
\hline & $\mathrm{N}$ & Minimum & Maximum & Mean & $\begin{array}{c}\text { Std. } \\
\text { Deviation }\end{array}$ \\
\hline $\begin{array}{l}\text { Literacy rate, adult total } \\
\text { (\% of people } 15+\text { ) }\end{array}$ & 31 & 78.60 & 100.00 & 94.8968 & 6.3986 \\
\hline $\begin{array}{l}\text { Primary education } \\
\text { particip. rate. (\%) }\end{array}$ & 27 & 77.00 & 116.00 & 100.1481 & 7.0586 \\
\hline $\begin{array}{l}\text { Infant survival (\%) } \\
\text { (100-mortality) }\end{array}$ & 47 & 94.40 & 99.57 & 99.0370 & .8180 \\
\hline $\begin{array}{l}\text { Health care }(\% \text { of } \\
\text { population with access) }\end{array}$ & 29 & 94.00 & 100.00 & 99.2862 & 1.6225 \\
\hline $\begin{array}{l}\text { Safe water (\% of } \\
\text { population with access) }\end{array}$ & 33 & 90.00 & 100.00 & 98.5393 & 2.4706 \\
\hline $\begin{array}{l}\text { Life expectancy at birth, } \\
\text { total (years) }\end{array}$ & 47 & 62.95 & 83.46 & 76.0917 & 3.0943 \\
\hline $\begin{array}{l}\text { GDP per capita, PPP } \\
\text { (constant } 1987 \\
\text { international } \$ \text { ) }\end{array}$ & 48 & 9147.22 & 25000.00 & 15831.97 & 3780.7309 \\
\hline
\end{tabular}

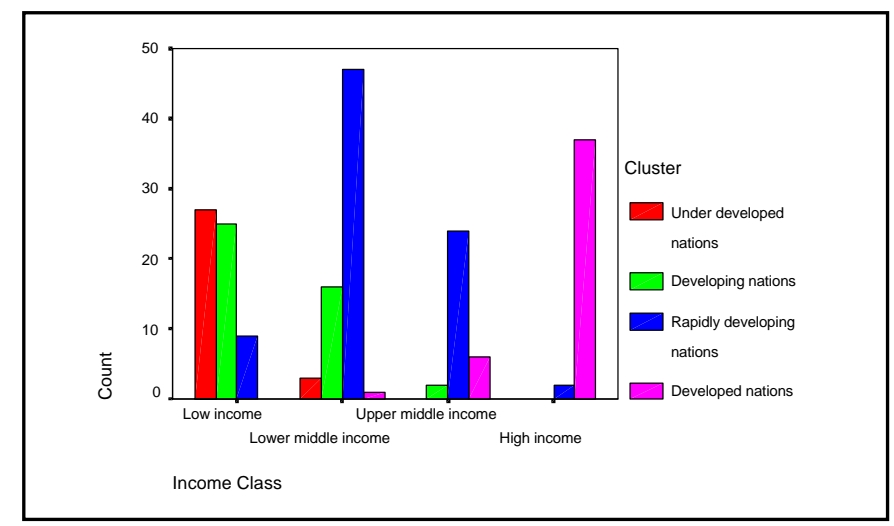

Figure 1. World Bank Income Class and Cluster Relationships

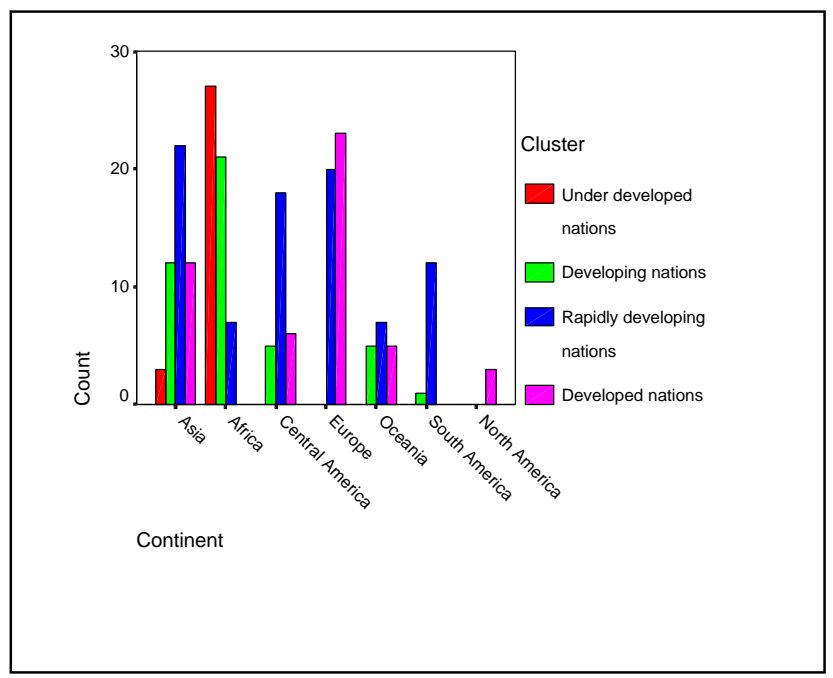

Figure 2. Social Development by Continent 
Table 5. Descriptive Statistics for Cluster 1: Poor Information Infrastructure Nations

\begin{tabular}{|l|r|r|r|r|r|}
\hline & N & Minimum & Maximum & Mean & \multicolumn{1}{c|}{$\begin{array}{c}\text { Std. } \\
\text { Deviation }\end{array}$} \\
\hline Telephone mainlines & 110 & .78 & 223.62 & 40.6000 & 45.6340 \\
(per 1,000 people) & & & & & \\
Television sets (per & 106 & 1.32 & 279.27 & 89.4720 & 80.7723 \\
1,000 people) & 108 & 31.92 & 875.00 & 200.0254 & 142.1524 \\
Radios (per 1,000 & 92 & .00 & 213.00 & 31.4761 & 37.5161 \\
people) & & &
\end{tabular}

Table 6. Descriptive Statistics for Cluster 4: Developing Information Infrastructure Nations

\begin{tabular}{|l|r|r|r|r|r|}
\hline & $\mathrm{N}$ & Minimum & Maximum & \multicolumn{1}{c|}{ Mean } & \multicolumn{1}{c|}{$\begin{array}{c}\text { Std. } \\
\text { Deviation }\end{array}$} \\
\hline $\begin{array}{l}\text { Telephone mainlines } \\
\text { (per 1,000 people) }\end{array}$ & 60 & 3.53 & 517.57 & 248.2673 & 122.4440 \\
$\begin{array}{l}\text { Television sets (per } \\
\text { 1,000 people) }\end{array}$ & 59 & 73.06 & 644.18 & 326.7984 & 117.4974 \\
$\begin{array}{l}\text { Radios (per 1,000 } \\
\text { people) }\end{array}$ & 60 & 62.02 & 1461.19 & 530.5934 & 251.7884 \\
Newspapers per 1000 & 49 & 2.00 & 297.00 & 133.1633 & 76.9676 \\
\hline
\end{tabular}

Table 7. Descriptive Statistics for Cluster 3: Rapidly Developing Information Infrastructure Nations

\begin{tabular}{|l|r|r|r|r|c|}
\hline & $\mathrm{N}$ & Minimum & Maximum & \multicolumn{1}{c|}{ Mean } & $\begin{array}{c}\text { Std. } \\
\text { Deviation }\end{array}$ \\
\hline $\begin{array}{l}\text { Telephone mainlines } \\
\text { (per 1,000 people) }\end{array}$ & 23 & 232.27 & 683.22 & 479.7179 & 121.1322 \\
$\begin{array}{l}\text { Television sets (per } \\
\text { 1,000 people) }\end{array}$ & 23 & 215.09 & 699.74 & 417.6840 & 117.0194 \\
Radios (per 1,000 & 22 & 184.52 & 1207.60 & 738.4567 & 271.6913 \\
people) & 19 & 250.00 & 757.00 & 472.7368 & 149.3917 \\
Newspapers per 1000 & 19 \\
\hline
\end{tabular}

Table 8. Descriptive Statistics for Cluster 2: Well Developed Information Infrastructure Nations

\begin{tabular}{|l|r|r|r|r|r|}
\hline & $\mathrm{N}$ & Minimum & Maximum & \multicolumn{1}{c|}{ Mean } & $\begin{array}{c}\text { Std. } \\
\text { Deviation }\end{array}$ \\
\hline $\begin{array}{l}\text { Telephone mainlines } \\
\text { (per 1,000 people) }\end{array}$ & 13 & 392.48 & 768.46 & 561.5967 & 91.4611 \\
$\begin{array}{l}\text { Television sets (per } \\
1,000 \text { people) }\end{array}$ & 13 & 509.29 & 1057.69 & 662.5298 & 145.5541 \\
$\begin{array}{l}\text { Radios (per 1,000 } \\
\text { people) }\end{array}$ & 13 & 886.32 & 2119.44 & 1227.090 & 316.1875 \\
Newspapers per 1000 & 13 & 104.00 & 473.00 & 273.4615 & 99.3140 \\
\hline
\end{tabular}

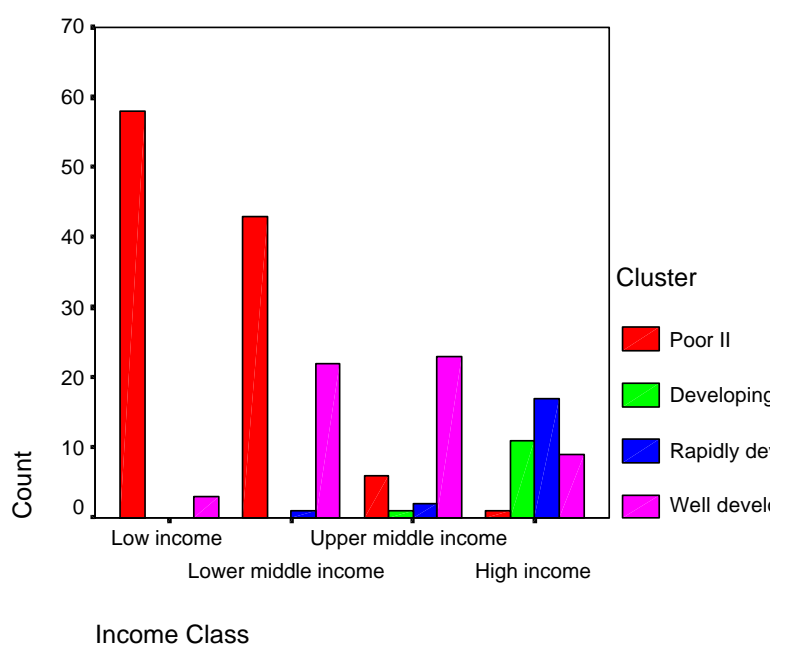

Figure 3. Level of Information Infrastructure by World Bank Income Group

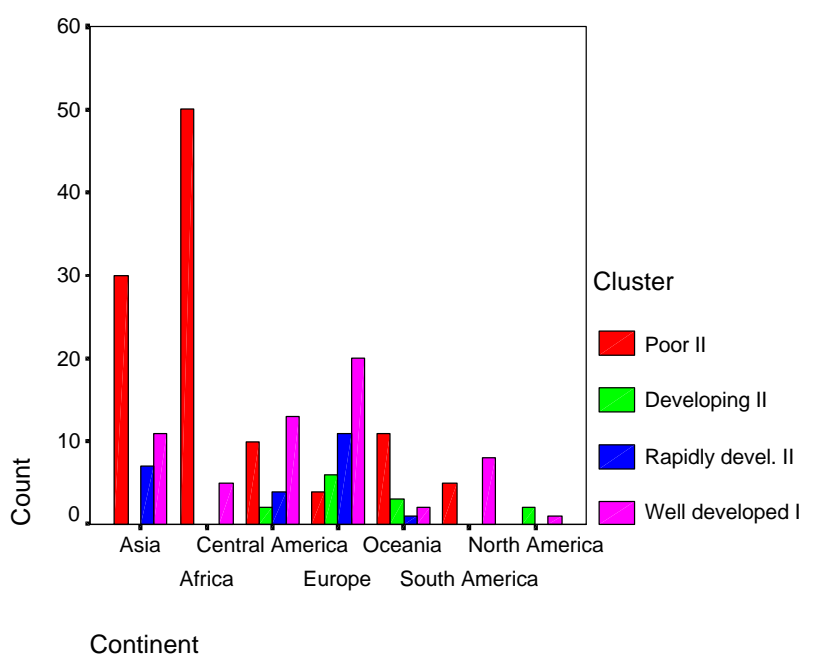

Figure 4. Level of Information Infrastructure by Continent 
Table 9. Descriptive Statistics for Cluster 2: Technology Poor Nations

\begin{tabular}{|l|r|r|r|r|r|}
\hline & $\mathrm{N}$ & Minimum & Maximum & \multicolumn{1}{c|}{ Mean } & \multicolumn{1}{c|}{$\begin{array}{c}\text { Std. } \\
\text { Deviation }\end{array}$} \\
\hline $\begin{array}{l}\text { High-technology exports } \\
\text { (\% of manufactured } \\
\text { exports) }\end{array}$ & 77 & .02 & 35.78 & 10.6602 & 8.3121 \\
$\begin{array}{l}\text { Internet hosts per 1M } \\
\text { population (WDI, 1998) }\end{array}$ & 115 & 0 & 17465 & 703.73 & 2106.55 \\
$\begin{array}{l}\text { updated 4/24/00 } \\
\begin{array}{l}\text { Expenditure on R\&D, as } \\
\text { \% of GNP }\end{array}\end{array} \quad 59$ & .00 & 1.70 & .4767 & .3505 \\
$\begin{array}{l}\text { Low tech investment \% } \\
\text { Med tech investment \% }\end{array}$ & 26 & 54.7 & 91.2 & 74.685 & 10.251 \\
$\begin{array}{l}\text { Num. users of Internet } \\
\text { per 1M popula-tion } \\
\text { Updated personal comp }\end{array}$ & 66 & 5.7 & 30.8 & 16.385 & 6.785 \\
/1000 pop. (4/24/00) & 78 & .17 & 26954.18 & 1696.151 & 4066.4451 \\
$\begin{array}{l}\text { High tech investment \% } \\
\text { GDP per capita, PPP } \\
\text { (constant 1987 } \\
\text { international \$) }\end{array}$ & 26 & 1.2 & 21.6 & 6.854 & 5.227 \\
\hline
\end{tabular}

Table 10. Descriptive Statistics for Cluster 4: Nations with Beginning Technology Development

\begin{tabular}{|l|r|r|r|r|r|}
\hline & $\mathrm{N}$ & Minimum & Maximum & \multicolumn{1}{|c|}{ Mean } & \multicolumn{1}{c|}{$\begin{array}{c}\text { Std. } \\
\text { Deviation }\end{array}$} \\
\hline $\begin{array}{l}\text { High-technology exports } \\
\text { (\% of manufactured } \\
\text { exports) } \\
\text { Internet hosts per 1M } \\
\text { population (WDI, 1998) }\end{array}$ & 17 & 33.81 & 94.01 & 49.3334 & 15.6475 \\
updated 4/24/00 & 19 & 2 & 32230 & 3340.95 & 7851.57 \\
$\begin{array}{l}\text { Expenditure on R\&D, as } \\
\text { \% of GNP }\end{array}$ & 15 & .00 & 1.51 & .4503 & .4991 \\
$\begin{array}{l}\text { Low tech investment \% } \\
\text { Med tech investment \% }\end{array}$ & 2 & 32.8 & 42.6 & 37.700 & 6.930 \\
$\begin{array}{l}\text { Num. users of Internet } \\
\text { per 1M popula-tion }\end{array}$ & 18 & 7.19 & 30135.61 & 4914.263 & 8603.4146 \\
$\begin{array}{l}\text { Updated personal comp } \\
\text { /1000 pop. (4/24/00) }\end{array}$ & 15 & 1.7 & 458.4 & 100.422 & 132.373 \\
$\begin{array}{l}\text { High tech investment \% } \\
\text { GDP per capita, PPP }\end{array}$ & 2 & 33.8 & 48.8 & 41.300 & 10.607 \\
(constant 1987 \\
international \$)
\end{tabular}

Table 11. Descriptive Statistics for Cluster 1: Nations with Rapidly Evolving Technology

\begin{tabular}{|l|r|r|r|r|r|}
\hline & $\mathrm{N}$ & Minimum & Maximum & \multicolumn{1}{|c|}{ Mean } & $\begin{array}{c}\text { Std. } \\
\text { Deviation }\end{array}$ \\
\hline $\begin{array}{l}\text { High-technology exports } \\
\text { (\% of manufactured } \\
\text { exports) } \\
\text { Internet hosts per 1M } \\
\text { population (WDI, 1998) }\end{array}$ & 22 & .59 & 37.69 & 18.2544 & 10.6734 \\
$\begin{array}{l}\text { updated 4/24/00 } \\
\text { Expenditure on R\&D, as } \\
\text { \% of GNP }\end{array}$ & 17 & 147 & 27060 & 9223.97 & 8887.26 \\
$\begin{array}{l}\text { Low tech investment \% } \\
\text { Med tech investment \% } \\
\begin{array}{l}\text { Num. users of Internet } \\
\text { per 1M popula-tion }\end{array}\end{array}$ & 4 & 46.5 & 55.9 & 48.875 & 4.684 \\
$\begin{array}{l}\text { Updated personal comp } \\
\text { /1000 pop. (4/24/00) }\end{array}$ & 22 & 1052.81 & 53485.47 & 13395.81 & 14661.41 \\
$\begin{array}{l}\text { High tech investment \% } \\
\text { GDP per capita, PPP } \\
\text { (constant 1987 }\end{array}$ & 4 & 28.7 & 304.7 & 164.817 & 84.048 \\
international \$) & 30 & 5137.22 & 25000.00 & 16019.50 & 4902.1968 \\
\hline
\end{tabular}


Table 12. Descriptive Statistics for Cluster 3: Technology Leaders

\begin{tabular}{|c|c|c|c|c|c|}
\hline & $\mathrm{N}$ & Minimum & Maximum & Mean & $\begin{array}{c}\text { Std. } \\
\text { Deviation }\end{array}$ \\
\hline $\begin{array}{l}\text { High-technology exports } \\
\text { (\% of manufactured } \\
\text { exports) }\end{array}$ & 12 & 8.88 & 45.08 & 25.7894 & 9.6432 \\
\hline $\begin{array}{l}\text { Internet hosts per } 1 \mathrm{M} \\
\text { population (WDI, 1998) } \\
\text { updated } 4 / 24 / 00\end{array}$ & 11 & 31007 & 150877 & 63303.68 & 36675.94 \\
\hline $\begin{array}{l}\text { Expenditure on R\&D, as } \\
\% \text { of GNP }\end{array}$ & 11 & 1.07 & 3.63 & 2.0618 & .7317 \\
\hline Low tech investment \% & 1 & 43.2 & 43.2 & 43.200 & \\
\hline Med tech investment \% & 1 & 30.9 & 30.9 & 30.900 & \\
\hline $\begin{array}{l}\text { Num. users of Internet } \\
\text { per } 1 \mathrm{M} \text { popula-tion }\end{array}$ & 11 & 35511.36 & 138997.7 & 60296.80 & 33931.12 \\
\hline $\begin{array}{l}\text { Updated personal comp } \\
/ 1000 \text { pop. }(4 / 24 / 00)\end{array}$ & 11 & 205.2 & 458.6 & 353.484 & 70.043 \\
\hline High tech investment \% & 1 & 25.3 & 25.3 & 25.300 & \\
\hline $\begin{array}{l}\text { GDP per capita, PPP } \\
\text { (constant } 1987 \\
\text { international \$) }\end{array}$ & 16 & 9000.00 & 20589.72 & 14510.86 & 3024.7619 \\
\hline
\end{tabular}

Table 13. Investment composition in some ex-Soviet sphere nations as \% of industry

\begin{tabular}{|c|c|c|c|}
\hline Country & $\mid \begin{array}{l}\text { Level of } \\
\text { technology }\end{array}$ & 1970 & 1994 \\
\hline \multirow[t]{3}{*}{ Hungary } & Low & 59.90 & 61.80 \\
\hline & Medium & 23.50 & 23.60 \\
\hline & High & 15.00 & 14.00 \\
\hline \multirow[t]{3}{*}{ Poland } & Low & 58.40 & 66.90 \\
\hline & Medium & 24.00 & 19.90 \\
\hline & High & 17.30 & 12.20 \\
\hline \multirow[t]{3}{*}{ Romania } & Low & 56.70 & 68.10 \\
\hline & Medium & 20.70 & 14.40 \\
\hline & High & 19.60 & 5.60 \\
\hline \multirow[t]{3}{*}{ Slovenia } & Low & 99.30 & 46.60 \\
\hline & Medium & 0.20 & 39.30 \\
\hline & High & 0.40 & 13.70 \\
\hline
\end{tabular}

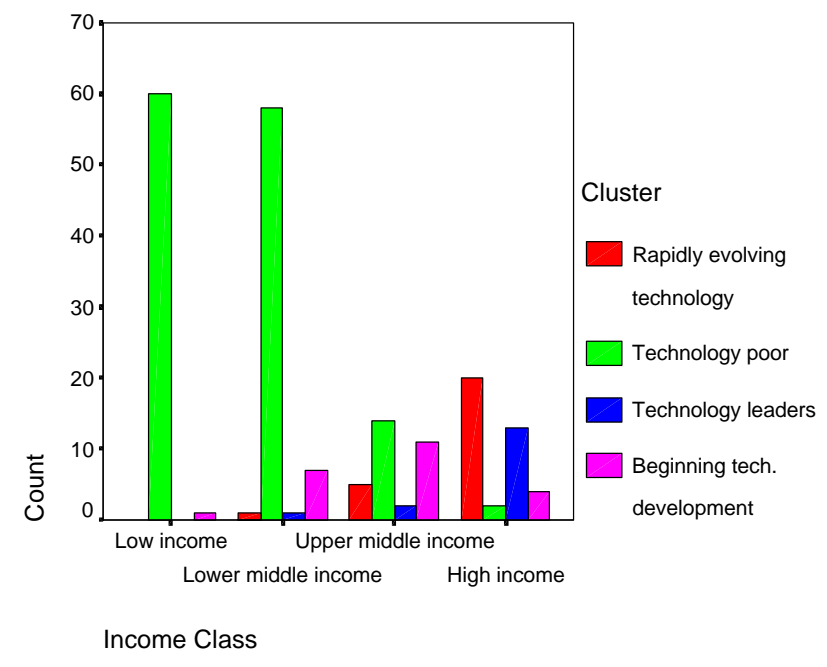

Figure 5. Level of Technology Development by World Bank Income Group

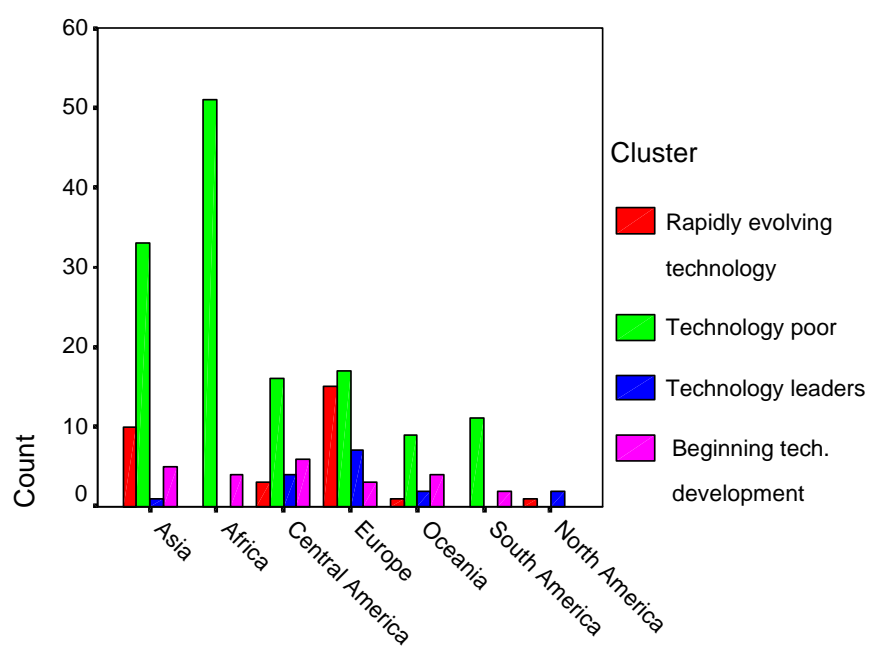

Continent

Figure 6. Level of Technology Development by Continent 


\section{Technology and Social Development}

\section{References}

Ferguson, K. (2000). World Information Flows and the Impact of New Technology: Is There a Need for International Communications Policy and Regulation? In Social Dimensions of Information Technology, ed. G. Garson, 323-339. Hershey, PA: Idea Group Publishing.

Investment in Africa: More than Expected. The Economist, June 3, 2000, p. 77.

Meso, Peter (1999). Relating Social Development to Information Infrastructure in the Least Developed Countries. Proceedings of the Decision Sciences Institute, (New Orleans, LA, November, 1999).

Why the productivity revolution will spread. Business Week, February 14, 2000, p. 112.

Rhode, Gregory L. (2000). "How do we know where we are going if we do not know where we are?" Retrieved November 27, 2000 from the World Wide Web:

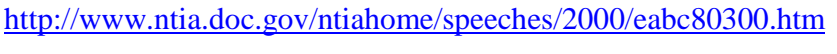

UNIDO (1997). Industrial development: global report 1997, (UNIDO, ID/IDRG/1997).

The Wall Street Journal Europe, Tuesday, June 6, 2000, p 3.

\section{Biographies}

Dr. László Poók is professor of information systems at Metropolitan State College of Denver. His areas of research include culture's impact on information needs, generation, presentation and usage, as well as the implications of information technology on societies.

Dr. Norman Pence is professor of information systems at Metropolitan State College of Denver. His areas of interest include statistical techniques primarily consisting of regression analysis, analysis of vareianc, and nonparametric statitstics. 